\title{
14
}

\section{China's trade expansion and the Asia Pacific economies}

Kunwang Li and Ligang Song

Chinese foreign trade expanded at an average annual rate of 17 per cent from 1979 to 2000, which was twice the average annual growth rate of China's GDP during the same period. Both growth rates have been considerably higher than the respective world averages over the same period. Accession to the WTO in 2001 has given new impetus to expansion of China's external trade. In 2003, China's total external trade reached US $\$ 851$ billion, an increase of 37 per cent from 2002China's first year as a member of the WTO. In that year, with total imports reaching US $\$ 413$ billion, China passed Japan to become the largest import market in Asia. With total external trade surpassing US $\$ 1000$ billion in 2004 , China has exceeded Japan and become the world's third largest trading nation after the United States and Germany.

China's emergence as a major exporter of a wide variety of manufactures in the past two decades has intensified the competitive impact on both industrial and developing economies alike. From the point of view of people in industrial economies who are involved in labour-intensive and other sectors, the Chinese comparative advantage is strong or strengthening and the expansion of China's exports hurts employment, especially for unskilled labour. This contributes to surges in trade protectionism against Chinese exports in industrial countries. Increasingly, these have taken the form of anti-dumping or other safeguard 
measures such as re-imposing quotas and setting limits on quantities or growth targets for certain Chinese exports entering their markets. ${ }^{1}$ Protectionism prompted the Chinese government to lobby intensely to be granted 'marketeconomy' status by other members of the WTO, especially industrial countries, in order to ease anti-dumping measures.

There are also anxieties among developing economies over China's rising trade. Developing economies are concerned that China's increasing exports will substitute for their exports in third markets. There are also concerns voiced in some developing economies, especially in East and Southeast Asia, that much needed foreign direct investment could be diverted to China, which has become a magnet in attracting FDI, especially in recent years. Developing economies fear that both trends will slow the growth in their exports and incomes (Lall 2004; Shafaeddin 2004; Song 2004; Weiss 2004).

What is the balance between competition and opportunites for China's trading partners? This chapter explores China's contributions to the trade expansion of China's major trading partners in Asia and the Pacific from 1990 to 2003. The economies included are China's major trading partners in East Asia, including Japan, Korea, Hong Kong, Taiwan, and the five major economies of ASEANIndonesia, Malaysia, the Philippines, Singapore and Thailand. Given the important role played by the United States in international as well as regional trade, the United States is also covered. The term 'region' in this chapter refers to East Asia plus the United States.

\section{Trade reform, comparative advantage and the rise of Chinese trade}

Chinese economy's remarkable international performance is based on the success of its domestic reform. These, together with trade liberalisation, directly affected China's external trade through increased specialisation, increased market size, and technological advance, supported by foreign direct investment (Song and Sun 2003). China's trade expansion has been based on its underlying comparative advantage, relying strongly on exports of labour-intensive products in its early expansionist period. And then the accumulation of capital in the process of growth saw comparative advantage shift progressively towards increasingly capital-intensive and then further to technology-intensive products. The relationships between factor endowments and trade patterns change over time in a dynamic fashion, with comparative advantage shifting as endowments change. These shifts expand export supply potential (Song 1996). 
With the Chinese economy increasingly dependent on a high degree of trade, it is less than ever in China's best interest to try to protect its domestic industries by limiting imports (Song and Sun 2003). As pointed out by McKinnon,

\begin{abstract}
keeping imports out reduces the effective demand for, and consequently the price of, foreign exchange relative to the domestic costs of labour, capital, intermediate inputs, and so on that producers of export products must pay. Since exporters sell in foreign markets at this less favourable 'real' exchange rate, they are caught in a profit squeeze, which reduces traditional exports and blocks new export development-particularly of manufactures (1973:134).
\end{abstract}

Furthermore, domestic reform conforming with the WTO requirements has further improved China's trading system, and helped facilitate the expansion of its imports through increased transparency and efficiency. Thus China's increasingly important position in world trade provides huge export opportunities for China's trading partners, as it introduces new competitive pressures on these economies.

In the period 1990-2003, China's exports and imports grew at the average rates of 16 and 17 per cent respectively. Exports and imports increased by 6 and 6.7 times respectively. In comparison, the growth rates of exports and imports in all developing economies were 9 and 8.7 per cent respectively. China's shares in world total exports and imports have increased from 1.8 and 1.5 per cent in 1990 to 5.9 and 5.3 per cent respectively in 2003 (Appendix Table C1 in Appendix C).

The rapid growth of China's exports cannot be separated from the growth of its imports. Amongst other reasons, this is because a large part of China's export industries are in processing trade, in which all or part of imported raw materials, intermediate inputs, and other inputs are exported after being processed or assembled. The share of processing trade in exports reached 55 per cent in 2003.

The economies from which China imports are mainly located in the Asia Pacific region, especially in East Asia. From 1990 to 2003, Japan remained the largest exporter to China, with its share of China's imports rising from 14.2 per cent in 1990 to 18 per cent in 2003 (Table 14.1). The second largest exporter to China is the European Union, with its share in China's imports reaching 13.2 per cent in 2003 despite following a declining trend from 1995. The US position has witnessed great changes during these years. It was the third largest exporter to China in 1990 after Japan and the European Union, with its share in China's imports reaching 12.2 per cent. By 2000, however, the United States was overtaken by Taiwan and Korea with respect to its share in China's total imports. In 2003, the United States' share in China's imports fell even further to 8.2 per cent, lagging behind Japan, Taiwan, ASEAN, and Korea. 


\section{Table 14.1 Sources of China's imports from selected economies,} 1990-2003 (per cent of the total)

\begin{tabular}{lrrrr}
\hline & 1990 & 1995 & 2000 & 2003 \\
Asia & 41.0 & 47.1 & 50.6 & 54.9 \\
ASEAN & 5.6 & 7.4 & 8.9 & 11.0 \\
Hong Kong & 27.1 & 6.5 & 9.6 & 2.7 \\
Japan & 14.2 & 21.9 & 17.8 & 18.0 \\
Korea & 0.4 & 7.8 & 10.0 & 10.5 \\
Taiwan & & 11.2 & 11.3 & 11.6 \\
United States & 12.2 & 12.2 & 9.6 & 8.2 \\
European Union & 17.0 & 16.1 & 13.4 & 13.2 \\
\hline
\end{tabular}

Source: International Monetary Fund, (various years). Direction of Trade Statistics Yearbook, International Monetary Fund, Washington, DC.

The East Asian economies' dependence on exports to the Chinese market has increased in recent years. Except for Hong Kong, the East Asian economies' exports to China grew faster than to other trading partners. By 2003, Taiwan, ASEAN and Korea had risen to become the third, fourth and fifth-largest exporters to China, with their shares in China's imports reaching 11.6, 11 and 10.5 per cent respectively. The trend towards accelerated growth of trade within East Asia has been strengthened in recent years. The emerging Chinese economy, with its strong tradeorientation, has played a pivotal role in boosting the push for closer economic integration in the East Asian region. East Asia's share of China's imports increased from 41 per cent in 1990 to 55 per cent in 2003 (Table 14.1).

There is great variety in the commodity composition of each economy's exports to China. In both 1990 and 2003, capital-intensive products were the largest component of US exports to China, representing around 70 per cent of total exports to China. Agriculture-intensive products were the second largest component at around 20 per cent (Table 14.2). Labour-intensive and minerals-intensive products occupied relatively small shares in China's imports from the United States, although the share of minerals-intensive products rose during this period. Japan's exports to China have been predominantly capital-intensive products, which rose steadily 
Table 14.2 Commodity composition of exports to China from the regional economies (per cent)

\begin{tabular}{|c|c|c|c|c|}
\hline & Iture-intensive & Minerals-intensive & Labour-intensive & Capital-intensive \\
\hline \multicolumn{5}{|c|}{ Indonesia } \\
\hline 1990 & 51.0 & 25.5 & 0.2 & 23.2 \\
\hline 1995 & 40.3 & 38.9 & 4.6 & 16.1 \\
\hline 2000 & 37.2 & 26.0 & 5.4 & 31.5 \\
\hline 2003 & 30.8 & 23.9 & 5.0 & 40.3 \\
\hline \multicolumn{5}{|c|}{ Japan } \\
\hline 1990 & 4.2 & 2.5 & 11.5 & 81.9 \\
\hline 1995 & 2.7 & 3.3 & 12.0 & 82.0 \\
\hline 2000 & 2.2 & 3.9 & 10.7 & 83.2 \\
\hline 2003 & 1.5 & 3.4 & 6.8 & 88.3 \\
\hline \multicolumn{5}{|c|}{ Malaysia } \\
\hline 1990 & 78.7 & 7.5 & 1.4 & 12.5 \\
\hline 1995 & 66.3 & 6.2 & 4.3 & 23.2 \\
\hline 2000 & 21.5 & 9.5 & 2.4 & 66.7 \\
\hline 2003 & 14.4 & 7.7 & 1.3 & 76.7 \\
\hline \multicolumn{5}{|l|}{ Korea } \\
\hline 1990 & 17.4 & 1.8 & 20.3 & 60.5 \\
\hline 1995 & 13.4 & 5.4 & 21.6 & 59.6 \\
\hline 2000 & 7.5 & 11.7 & 13.6 & 67.4 \\
\hline 2003 & 3.2 & 6.8 & 7.5 & 82.6 \\
\hline \multicolumn{5}{|c|}{ Philippines } \\
\hline 1990 & 31.7 & 30.1 & 1.4 & 36.8 \\
\hline 1995 & 22.0 & 61.2 & 3.7 & 13.1 \\
\hline 2000 & 6.8 & 12.6 & 0.7 & 79.9 \\
\hline 2003 & 2.3 & 4.6 & 0.4 & 92.8 \\
\hline \multicolumn{5}{|c|}{ Singapore } \\
\hline 1990 & 19.5 & 48.4 & 3.6 & 28.4 \\
\hline 1995 & 20.9 & 31.9 & 10.5 & 36.6 \\
\hline 2000 & 1.5 & 18.1 & 2.7 & 77.6 \\
\hline 2003 & 1.3 & 15.8 & 2.2 & 80.7 \\
\hline \multicolumn{5}{|c|}{ Thailand } \\
\hline 1990 & 77.8 & 1.1 & 7.3 & 13.8 \\
\hline 1995 & 37.4 & 4.7 & 13.7 & 44.2 \\
\hline 2000 & 21.2 & 10.0 & 3.1 & 65.6 \\
\hline 2003 & 17.2 & 8.6 & 3.0 & 71.2 \\
\hline \multicolumn{5}{|c|}{ United States } \\
\hline 1990 & 25.7 & 2.7 & 2.7 & 69.0 \\
\hline 1995 & 25.8 & 4.1 & 3.5 & 66.6 \\
\hline 2000 & 16.5 & 5.2 & 2.0 & 76.3 \\
\hline 2003 & 20.1 & 5.1 & 2.2 & 72.7 \\
\hline
\end{tabular}

Source: Authors' calculations using the data from UN Comtrade database. 
from 81.8 per cent in 1990 to 88.3 per cent in 2003. Japan's exports of labourintensive products to China fell continuously from 11.5 per cent in 1990 to 6.8 per cent in 2003. A similar trend can also be observed for Korea, where the share of labour-intensive products in exports to China fell from 20 per cent in 1990 to about 7 per cent in 2003, providing more evidence of shifting comparative advantage in the process of East Asian industrialisation.

The commodity composition of ASEAN's exports to China has changed a great deal over the same period. In the early 1990s, ASEAN's exports to China were mainly of agriculture-intensive and minerals-intensive products, followed by capitalintensive and labour-intensive products. In 2002, however, capital-intensive products had become the major component in ASEAN's exports to China, followed by agriculture-intensive products and minerals-intensive products. The share of capitalintensive products in ASEAN's exports to China continued to rise to 72.1 per cent in 2003, while the shares of agriculture-intensive and minerals-intensive products were falling. The pattern of bilateral trade between China and ASEAN bears further study, including by looking intra rather than inter-industry trade (see Chapter 13).

There are variations in commodity composition within the ASEAN five in relation to China. While agriculture-intensive and minerals-intensive products remained the major components in Indonesia's exports to China, their shares are declining and the share of capital-intensive products rising. At the beginning of the 1990s, Malaysian exports to China were mainly concentrated on agriculture-intensive products, but the share of these goods dropped drastically after 1995 when capitalintensive products' share was on the rise. The situation with the Philippines and Thailand is similar to that of Malaysia. Singapore demonstrated a different pattern from other members in ASEAN as the share of minerals-intensive products in its exports to China was relatively high, due to its role as an important re-exporter of related products.

Despite all the differences, there is similarity among China's imports from the members of ASEAN - all export only low proportions of labour-intensive products to China. To study the bilateral trading relationships between China and ASEAN further, an export similarity index was used, defined as the degree of similarity between the commodity composition of China's exports to ASEAN and that of ASEAN's exports to China. If this index increases, it indicates a convergence of the structure of the two trade partners' exports, and also suggests greater competition between the two partners in third-country markets. On the other hand, a decline in the index suggests that specialisation between them is increasing in a third market. Furthermore, if the convergence occurs between a developing 
country and an industrial economy, rising indexes can also be interpreted as a reflection of fast growth and industrialisation for the developing country ( $\mathrm{Xu}$ and Song 2000).

Table 14.3 provides the bilateral export similarity indexes between China and the five members in ASEAN. Except for Indonesia and the Philippines, the bilateral export similarities between China and Malaysia, Thailand and Singapore have been steadily increasing (statistically significant at the 1 per cent, 5 per cent, and 10 per cent levels respectively). Increase in trade overlap between China and the three members of ASEAN indicates that there has been a convergence in their industrial and export structures, and greater competition between them in thirdcountry markets. The increasing similarity in their export structure, together with increased intensity of bilateral trade, suggests that the patterns of trade between China and ASEAN are of intra-industry, rather than inter-industry, trade. For example, the large amount of capital-intensive products among ASEAN exports to China has a great deal to do with multinational corporations' direct investment in East Asia.

The recent surge in bilateral trade between China and ASEAN indicates that a new pattern of trade has begun to emerge between the two, driven primarily by firms seeking economies of scale and product differentiation through the operation of multinational corporations. The formation of the bilateral free trade arrangement (FTA), the so-called ' $10+1$ ', can be expected to strengthen bilateral trade between

\section{Table 14.3 The bilateral export similarity index between China and} ASEAN countries, 1995-2003

\begin{tabular}{lccccc}
\hline & Indonesia & Malaysia & Philippines & Singapore & Thailand \\
1995 & 0.330 & 0.520 & 0.307 & 0.557 & 0.435 \\
1996 & 0.322 & 0.529 & 0.256 & 0.504 & 0.381 \\
1997 & 0.274 & 0.537 & 0.426 & 0.513 & 0.479 \\
1998 & 0.314 & 0.561 & 0.607 & 0.553 & 0.509 \\
1999 & 0.301 & 0.596 & 0.664 & 0.637 & 0.605 \\
2000 & 0.243 & 0.635 & 0.612 & 0.650 & 0.554 \\
2001 & 0.299 & 0.634 & 0.410 & 0.610 & 0.514 \\
2002 & 0.332 & 0.634 & 0.419 & 0.574 & 0.550 \\
2003 & 0.369 & 0.539 & 0.461 & 0.585 & 0.502 \\
Spearman & & & & & \\
coefficient & 0.345 & $0.770^{\star * *}$ & 0.503 & $0.588^{*}$ & $0.697^{* *}$ \\
p-value & 0.328 & 0.009 & 0.138 & 0.074 & 0.025 \\
\hline
\end{tabular}

Note: The estimates with ${ }^{* * *},{ }^{* *},{ }^{*}$ denotes significance at 1 per cent, 5 per cent and 10 per cent levels respectively.

Source: Authors' calculations. 
Table 14.4 Impact of ' $10+1$ ' gain in regional economies' exports to China (change in per cent)

\begin{tabular}{lcccccccc}
\hline Indonesia & Malaysia & Japan & Korea & Philippines & Singapore & Taiwan & Thailand & US \\
28.38 & 29.96 & 1.19 & 0.03 & 36.12 & 29.75 & 0.42 & 30.03 & 0.51 \\
\hline
\end{tabular}

Source: Calculated by Zhang Bowei based on the GTAP modeling techniques with the base year of 1997.

ASEAN and China further. To assess the potential impact of this regional grouping on region's economies, a simulation analysis is carried out by employing the computable general equilibrium (CGE) model based on the GTAP to examine how China's imports from the regional economies will change after the realisation of free trade between China and ASEAN.

Trade liberalisation between China and ASEAN will enchance ASEAN's exports to China considerably (Table 14.4). This appears especially significant to two members of ASEAN-the Philippines and Thailand. For the economies outside ' $10+1$ ', while trade liberalisation between China and ASEAN produces no negative effect on their exports to China, the positive effects are minimal, especially for Korea, Taiwan and the United States. Formation of a bilateral FTA between China and ASEAN could reduce their engagement with other regional economies as engagement with each other comes to dominate, yielding new pressures within China, ASEAN and the other economies.

Diminished gains from trade accompany a diminished pressure to adjust. The FTAinduced separation of third countries, including economies in the region, from East Asian dynamism reduces opportunities for rising living standards. This is likely to be most damaging to potential suppliers of the natural resource-based products in which China's comparative disadvantage is most pronounced, and especially in agricultural industries in which trade distortion is endemic. The trade-off between costs of adjustment and gains from trade through the rise of China is affected by the presence of FTAs. For the world as a whole, the trade-off between adjustment costs and gains from trade is more favourable if the movement is towards specialisation according to global comparative advantage, as it is modified by growth and structural change in individual economies (Garnaut and Song forthcoming). This message becomes clearer through China's contributions to regional trade and economic growth. 


\section{China's contributions to regional export growth}

The Asia Pacific economies continued to perform well above world average in terms of growth of trade from 1990 to 2003. The total exports of the Asia Pacific economies (including the United States) increased 1.4 times over this period. The growth rate of the 10 developing economies was much higher than that of the two industrial countries, the United States and Japan. Within the developing economies, China's exports grew the fastest, followed by ASEAN, South Korea, Taiwan and Hong Kong. What have been the major sources of rapid growth of the regional economies' exports?

Employing the method described in Appendix A, the eleven regional economies' export growth can be decomposed into three components. The first component is the demand effect, which reflects the inducement from overall world trade expansion. The second, a competitiveness effect, represents the improvement in an economy's international competitiveness either through price or product quality. An economy can increase its share in the world market by expanding its exports faster than the world average. Thus, changes in export share in world markets provide an indication of changes in an economy's international competitiveness. The first two effects will basically determine an economy's export growth. However, there is a deviation between the sum of these two parts and the realised-growth rate. The reason for this deviation is that there are some factors, such as geographical proximity, social and cultural ties, special trade arrangements that may lead to an uneven distribution of an economy's exports among its various trading partners. Thus, the third effect is introduced as the location effect, which includes all factors other than the first two.

Table 14.5 reports the results of the decomposition of the three effects for the eleven economies as well as the region's total export growth. First, the demand effect is very prominent in the region's export growth. On the whole, the region's total exports increased by 142 per cent over the period 1990-2003, of which 135 percentage points were brought about by the demand effect. That is, the demand effect contributed 95 per cent of total growth ( 135 per cent/142 per cent), while the competitiveness effect contributed 25 per cent, and the location effect -18.8 per cent.

Second, the region's developing economies have seen exports grow more through improvements in their international competitiveness-China, Malaysia, the Philippines and Thailand, in particular, benefited more from increased international competitiveness driving export growth. In contrast, for NIEs, the contribution of the demand effect exceeds that of the competitiveness effect. This is especially 
Table 14.5 Decomposition of export growth of the regional economies (per cent)

\begin{tabular}{|c|c|c|c|c|}
\hline (a)1990-2003 & Total & Demand & Competitiveness & Location \\
\hline China & 598.3 & 137.2 & 512.1 & -51.0 \\
\hline Hong Kong & 172.5 & 256.1 & 83.0 & -166.5 \\
\hline Indonesia & 137.6 & 117.6 & 16.3 & 3.6 \\
\hline Japan & 64.7 & 140.7 & -61.3 & -14.7 \\
\hline Korea & 184.2 & 116.1 & 61.8 & 6.3 \\
\hline Malaysia & 256.8 & 125.1 & 138.3 & -6.7 \\
\hline Philippines & 342.1 & 124.7 & 224.8 & -7.3 \\
\hline Singapore & 178.6 & 140.2 & 57.3 & -18.8 \\
\hline Taiwan & 174.6 & 147.6 & 60.0 & -33.0 \\
\hline Thailand & 248.2 & 121.7 & 127.6 & -1.2 \\
\hline United States & 84.1 & 110.7 & -35.2 & 8.6 \\
\hline $\begin{array}{l}\text { Region } \\
\text { (b)1990-1995 }\end{array}$ & 142.4 & 135.8 & 25.4 & -18.8 \\
\hline China & 137.3 & 85.0 & 115.6 & -63.2 \\
\hline Hong Kong & 111.3 & 74.2 & 77.7 & -40.7 \\
\hline Indonesia & 76.9 & 57.3 & 33.2 & -13.6 \\
\hline Japan & 54.0 & 60.3 & 8.7 & -15.0 \\
\hline Korea & 93.6 & 52.1 & 49.5 & -8.0 \\
\hline Malaysia & 150.6 & 67.3 & 119.7 & -36.4 \\
\hline Philippines & 112.0 & 54.8 & 69.8 & -12.7 \\
\hline Singapore & 126.1 & 74.7 & 94.5 & -43.1 \\
\hline Taiwan & 86.7 & 66.9 & 46.4 & -26.6 \\
\hline Thailand & 147.9 & 55.5 & 108.4 & -15.9 \\
\hline United States & 48.4 & 45.0 & 2.3 & 1.1 \\
\hline $\begin{array}{l}\text { Region } \\
\text { (c) 1995-2000 }\end{array}$ & 74.4 & 57.8 & 32.7 & -16.2 \\
\hline China & 67.3 & 23.5 & 37.6 & 6.2 \\
\hline Hong Kong & 16.4 & 45.8 & -13.5 & -15.9 \\
\hline Indonesia & 36.7 & 25.3 & 8.2 & 3.2 \\
\hline Japan & 7.9 & 31.8 & -20.9 & -3.0 \\
\hline Korea & 30.9 & 29.2 & 2.6 & -0.9 \\
\hline Malaysia & 33.1 & 25.8 & 4.8 & 2.6 \\
\hline Philippines & 119.9 & 32.3 & 94.5 & -6.9 \\
\hline Singapore & 17.9 & 24.1 & -11.4 & 5.2 \\
\hline Taiwan & 32.7 & 32.5 & 4.5 & -4.4 \\
\hline Thailand & 20.6 & 26.4 & -7.6 & 1.8 \\
\hline United States & 32.3 & 22.6 & 3.9 & 5.9 \\
\hline Region & 27.5 & 28.4 & -1.2 & 0.3 \\
\hline
\end{tabular}




\section{Table 14.5 Decomposition of export growth of the regional economies} (per cent) cont.

\begin{tabular}{lrrrr}
\hline & Total & Demand & Competitiveness & Location \\
(d)2000-2003 & & & & \\
China & 75.9 & 10.6 & 54.4 & 10.9 \\
Hong Kong & 10.8 & 36.4 & -8.2 & -17.4 \\
Indonesia & -1.8 & 12.0 & -18.7 & 5.0 \\
Japan & -0.9 & 15.2 & -18.4 & 2.3 \\
Korea & 12.2 & 18.5 & -5.8 & -0.5 \\
Malaysia & 7.0 & 10.3 & -10.3 & 6.9 \\
Philippines & -5.2 & 9.1 & -21.4 & 7.1 \\
Singapore & 4.8 & 12.8 & -13.2 & 5.1 \\
Taiwan & 10.8 & 20.3 & -7.2 & -2.2 \\
Thailand & 16.5 & 12.4 & -1.4 & 5.5 \\
United States & -6.3 & 19.4 & -24.5 & -1.2 \\
Region & 9.0 & 17.8 & -9.4 & 0.6 \\
\hline
\end{tabular}

Source: Authors' calculations.

so for the United States and Japan, whose export growth was determined by demand rather than competitiveness. This seems to suggest that the more developed the economy, the more likely it is to depend on demand rather than competitiveness to sustain export growth. In fact, for industrialised economies, the contribution of competitiveness to export growth was actually negative as they are losing international competitiveness over a wide spectrum of manufacturing products. In the case of China, the demand effect is important, but the competitiveness effect plays an overwhelming role in sustaining its rapid export growth.

Third, there is a dynamic feature in these three effects over the different periods. The demand effect in regional export growth continued to play an important role in enhancing export expansion in the region's economies over the sub-periods, although its contribution fell over time. The competitiveness effect is falling, presumably because of the strong influence of the industrial economies. Interestingly, the location effect has become more and more important in the regional economies over time, especially during 2000-2003. The next step is to look at how China contributes to the demand effect of regional trade.

China's impact on regional economies' trade expansion can be assessed by looking at China's contribution to the demand effect component of other economies' export expansion. Table 14.6 provides the results of this estimation. For comparison, the estimation also includes the contributions made by the two largest economies in the Asia Pacific region-the United States and Japan. 
During the period 1990-2003, the proportion of the US contribution to the regional demand effect was 19.1 per cent, making it the largest contributor among the three, followed by China, which contributed 16.2 per cent. Japan's contribution is comparatively low at a mere 4.6 per cent, reflecting the sluggishness of the Japanese economy and Japan's declining role in leading regional economic growth since the early 1990 s.

By looking at the results over different periods, it can be seen that China's contribution to the demand effect has been rising continuously. Before 2000, the US contribution led, but things began to change dramatically after 2000 . In the period 2000-2003, China's role increased rapidly to 32.8 per cent, and the US role fell drastically from 33.2 per cent during 1995-2000 to about 5 per cent during 2000-2003. Japan's becomes inconsequential, a mere 0.4 per cent.

Except for the Philippines, to which China and the United States contirbute roughly equal effects in raising the demand for export growth, China has had a more powerful role in the export growth of all other regional economies. Within the region, China's impact in raising NIEs' export growth was stronger than that of ASEAN. Among the NIEs, Hong Kong is the largest beneficiary from rising demand in China, followed by Taiwan and Korea. Compared with the previous period, 19952000, China's contributions to the demand effect of export growth of ASEAN increased substantially. China has now become an engine for driving export growth in the region's economies.

\section{Industrial linkages between China and the regional economies through trade}

To analyse the impact of China's final demand on regional economies' production, an index of international division of labour (IDL) is introduced. The index is defined as the ratio of each economy's value-added to the total value-added in the region by sector, generated by an extra unit of demand in that sector in China. The index can be constructed by using an input-output methodology, which allows us to calculate and assess China's impact on regional economies through trade at the industrial level (see Appendix 14B for details). The data required are from the Asian International Input-Output Table 1995, published by the Institute of Developing Economies.

The degrees of international division of labour between China and other regional economies as defined are shown in Table 14.7. For each sector, the figures across different economies (rows) sum to unity, indicating the extent to which an extra unit of demand from China is being distributed. In sector 1-agriculture, livestock, forestry and fishery-98 per cent of China's demand is met within China and 
Table 14.6 China's contributions to the demand effect of export growth of the regional economies in comparison with the United States and Japan (per cent)

\begin{tabular}{|c|c|c|c|}
\hline & China & United States & Japan \\
\hline \multicolumn{4}{|l|}{ (a) $1990-2003$} \\
\hline China & & 9.4 & 6.7 \\
\hline Hong Kong & 64.5 & 14.4 & 1.4 \\
\hline Taiwan & 15.3 & 37.1 & 5.4 \\
\hline Indonesia & 18.4 & 17.0 & 22.7 \\
\hline Japan & 10.1 & 34.3 & 0.0 \\
\hline Korea & 0.0 & 10.1 & 37.6 \\
\hline Malaysia & 11.2 & 20.6 & 7.7 \\
\hline Philippines & 4.0 & 46.3 & 10.0 \\
\hline Singapore & 7.2 & 23.1 & 3.9 \\
\hline Thailand & 6.4 & 28.4 & 8.9 \\
\hline United States & 7.4 & 0.0 & 7.0 \\
\hline $\begin{array}{l}\text { Region } \\
\text { (b)1990-1995 }\end{array}$ & 16.2 & 19.2 & 4.6 \\
\hline China & 0.0 & 4.9 & 7.4 \\
\hline Hong Kong & 48.5 & 15.7 & 3.3 \\
\hline Taiwan & 7.4 & 26.4 & 8.2 \\
\hline Indonesia & 8.3 & 11.2 & 31.8 \\
\hline Japan & 5.2 & 25.8 & 0.0 \\
\hline Korea & 0.0 & 27.0 & 15.3 \\
\hline Malaysia & 4.6 & 12.4 & 9.7 \\
\hline Philippines & 2.0 & 34.0 & 15.5 \\
\hline Singapore & 3.0 & 14.0 & 5.0 \\
\hline Thailand & 3.1 & 20.1 & 13.3 \\
\hline United States & 4.0 & 0.0 & 11.8 \\
\hline $\begin{array}{l}\text { Region } \\
\text { (c)1995-2000 }\end{array}$ & 8.3 & 14.5 & 7.4 \\
\hline China & 0.0 & 42.8 & 10.5 \\
\hline Hong Kong & 51.1 & 28.8 & 1.7 \\
\hline Taiwan & 25.7 & 45.3 & 4.6 \\
\hline Indonesia & 10.6 & 33.3 & 13.9 \\
\hline Japan & 10.9 & 52.4 & 0.0 \\
\hline Korea & 16.8 & 38.5 & 5.8 \\
\hline Malaysia & 7.0 & 48.9 & 6.3 \\
\hline Philippines & 2.6 & 67.2 & 6.3 \\
\hline Singapore & 6.8 & 45.9 & 4.2 \\
\hline Thailand & 7.6 & 40.4 & 8.1 \\
\hline United States & 6.3 & 0.0 & 6.3 \\
\hline Region & 15.9 & 33.2 & 4.2 \\
\hline
\end{tabular}


Table 14.6 China's contributions to the demand effect of export growth of the regional economies in comparison with the United States and Japan (per cent) cont.

\begin{tabular}{lrcc}
\hline & China & United States & Japan \\
(d)2000-2003 & & & \\
China & 0.0 & 10.7 & 1.5 \\
Hong Kong & 79.2 & 3.5 & 0.1 \\
Taiwan & 54.2 & 6.8 & 0.5 \\
Indonesia & 31.1 & 6.2 & 1.8 \\
Japan & 35.0 & 10.8 & 0.0 \\
Korea & 48.5 & 6.5 & 0.6 \\
Malaysia & 25.0 & 10.8 & 1.2 \\
Philippines & 16.0 & 17.9 & 1.5 \\
Singapore & 25.4 & 7.3 & 0.5 \\
Thailand & 27.5 & 9.4 & 1.1 \\
United States & 8.9 & 0.0 & 0.4 \\
Region & 32.9 & 5.0 & 0.4 \\
\hline
\end{tabular}

Source: Authors' calculations.

about 2 per cent is divided among the other regional economies. Among these, the United States and Japan are benefiting more than the other economies in this sector.

Overall rankings are United States, Japan, Korea, Taiwan, Indonesia, Malaysia, Singapore, Thailand and Philippines, which suggests that increased demand in China benefited industrial economies more than the developing economies in the region. The international division of labour between China and the United States, Japan, South Korea and Taiwan is greater than that between China and all members in ASEAN except Indonesia. This difference in IDL indicates that China's trade dependence on the industrial economies and the NIEs within the region is higher than its dependence on the ASEAN economies.

For individual sectors, China's indices of IDL in transport equipment, machinery, chemicals, paper products, presswork and textiles are relatively low (approximately 90 per cent), suggesting that China's demand for those products is more heavily dependent on world markets. For example, China's demand for both machinery and transport equipment had to be met chiefly by Japan and to a lesser degree the United States in the mid 1990s; and Japan, the United States plus NIEs were relatively more important in providing other manufacturing goods to China. 
In comparison, China's indices of IDL in sectors such as agriculture, food, energy and minerals are relatively high, suggesting China relied more on domestic supplies to meet demand at that time. The figures show that China relied relatively more on Malaysia to meet its demand for timber and Thailand to meet its demand for rubber.

In brief, the degree and pattern of international division of labour between China and other regional economies largely reflected underlying comparative advantage. In relation to other regional economies, China relied more on imports of capitalintensive products and on exports of labour-intensive products. This is consistent with the finding that China has been importing increasing amounts of capitalintensive products from other economies in the region.

For energy and mineral sources, the results presented here were obtained based on 1995 data, when China's energy and mineral sectors still had a relatively high degree of self-sufficiency. As China's economy and trade rapidly expand, however, it will depend more and more on foreign resources, including energy and raw materials, to meet domestic demand, as demonstrated by the surge of China's demand for these products in recent years.

\section{Conclusion}

This chapter has examined how China has played an important role in enhancing the export expansion of its trading partners, through increasing imports from the regional economies. We examined the sources of export growth of these economies and their international industrial linkages with China. The results show that China has played an increasingly important role in the rapid development of the Asia Pacific region since 1990. China replaced Japan as the engine of regional trade growth in the second half of the 1990s. Since 2000, China has surpassed the United States and become the most powerful engine in the region's trade expansion.

The emergence of China into the world market has resulted in significant competitive pressures on other East Asian economies, but it has at the same time offered enormous opportunities to other Asian and Pacific economies. To take these opportunities, it is important for both China and its regional trading partners to continue to adjust their industrial structures in response to intensifying competition in the regional economies. A closer trading relationship centering on China in the East Asian region is now taking shape. It is imperative for the regional economies to maintain an open trading regime as such a regime underscored the great achievements of the regional economies in the past decades. And there is no doubt that such a regime will continue to play an important role in securing the region's prosperity in the future. 
荦

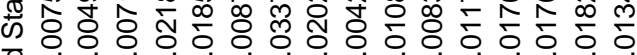

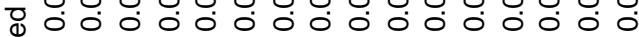
空

๙

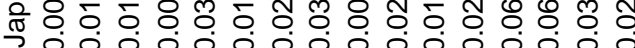

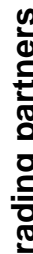

๘

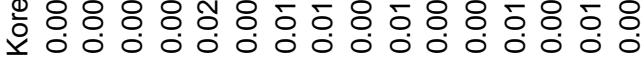

응

en

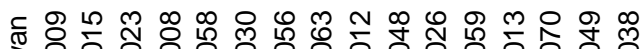

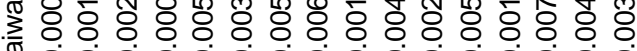
苗 000 O

ఫ

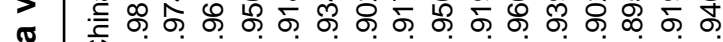

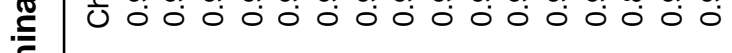

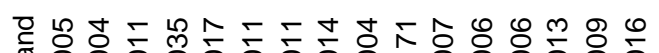

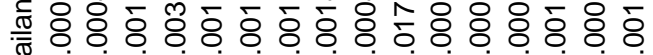

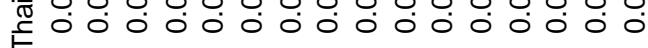

花 드

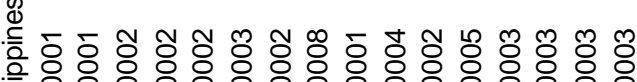

은

$\frac{\pi}{n} \infty \stackrel{0}{2}$ న ส্ঠ

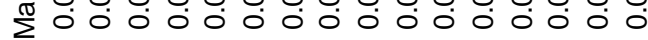

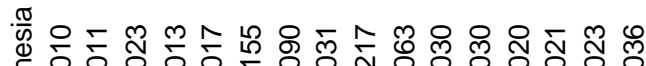

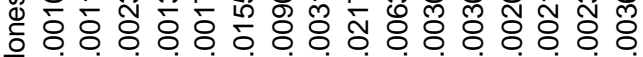
$\checkmark \quad$ O İ

$\frac{0}{\frac{0}{0}}$ 产

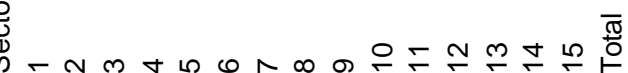




\section{Acknowledgments}

The authors would like to thank Shi Binzhan for his valuable help with processing the data and Zhang Bowei for his input in carrying out the CGE modeling work.

\section{Notes}

See the recent trade disputes between China and the European Union over imports of textile/ clothing into the EU markets.

\section{References}

Garnaut, R. and Song, L., (forthcoming).'Truncated globalisation: the fate of the Asia Pacific economies?', in H. Soesastro and C. Findlay (eds), Reshaping the Asia Pacific Economic Order, Routledge, London.

Institute of Developing Economies (IDE), 2001. Asian International Input-Output Table 1995, IDE Statistical Data Series 82, Tokyo.

Lall, S., and Albaladejo, M., 2002. 'The competitive impact of China on manufactured exports by emerging economies of Asia', in C.A. Magarinos, Y. Tu and F.C. Sercovich (eds), China in the WTO: the birth of a catching-up strategy, Palgrave Macmillan, Houndmills:76-110.

— 2004 . 'China's competitive performance: a threat to East Asia manufactured exports?', World Development, 32(9):1441-66.

$\mathrm{Li}, \mathrm{K}$. and Xue, J. 1998. 'Regional trade growth among APEC: an empirical analysis' (APEC qu yu nei mao yi zeng zhang de yin su fen xi), World Economy, 1:43-50. McKinnon, R.I., 1973. Money and Capital in Economic Development, The Brookings Institute, Washington, DC.

Sano, T. and Chihatru T., 1993. International Industrial Linkages and Economic Interdependency in Asia-Pacific Region, Institute of Developing Economies, Tokyo.

Shafaeddin, S. M., 2004. 'Is China's accession to WTO threatening exports of developing countries?', China Economic Review, 15(2):109-44.

Song, L., 1996. 'Institutional change, trade composition and export supply potential in China', in M.Guitian and R. Mundell (eds), Inflation and Growth in China, International Monetary Fund, Washington, DC:190-225.

— and Song, S., 2003. 'A changing role in world trade', in R. Garnaut and L. Song (eds), China: New Engine of World Growth, Asia Pacific Press, Canberra:151-75. 
Song, L., 2004. 'The export competitiveness of ASEAN, China and the East Asia NIEs, 1987-2000', proceedings of Rising China and the East Asian Economy conference, The Korea Institute for International Economic Policy, Seoul, 1920 March.

Weiss, J., 2004. People's Republic of China and its neighbours: partners or competitors for trade and investment?, ADB Institute Discussion Paper 12, Asian Development Bank Institute, Tokyo.

$\mathrm{Xu}, \mathrm{X}$. and Song, L., 2000. 'Export similarity and the pattern of East Asia development', in P. Lloyd and X. Zhang (eds), China in the Global Economy, Edward Elgar, Cheltenham:154-64.

Xue, J. and Zhang B., 2004. 'Free trade agreements in East Asia: a simulation analysis using the computable general equilibrium modeling techniques', World Economy, 6:51-59. 


\section{Appendix 14A Decomposition of export growth}

Let $X=\left(x_{i j}\right)$ be the trade matrix among the economies in the region, where $x_{i j}$ denotes the trade flow from economy $i$ to economy $j$.

The sum by row is total exports $\left(X_{j}\right)$ and the sum by column is total imports $\left(M_{j}\right)$ of the economy $\mathrm{j}$ as follows

$$
\begin{aligned}
\sum_{j} x_{i j} & =X_{i} \\
\sum_{i} x_{i j} & =M_{j}
\end{aligned}
$$

Changes in total imports of economy $j$ between time $t$ and 0 will be expressed as

$$
\beta_{j}=\frac{M_{j}^{t}}{M_{j}^{0}}
$$

which reflects the changes in domestic demand for imports.

Changes in economy is position in the world market are reflected in the changes in relative competitiveness of the economy, which can be measured by the change in the share of exports of economy $i$ in the world trade $\left(X_{w}\right)$ as

$$
\alpha_{i}=\frac{s_{i}^{t}}{s_{i}^{0}}=\frac{X_{i}^{t} / X_{w}^{t}}{X_{i}^{0} / X_{w}^{0}}
$$

Assuming that the improvement of economy is competitiveness prevails in all the markets at the same rate, economy is exports to economy $j$ expand at the same rate as the growth rate of economy is total exports. However, the realised export at time $t$ might differ from this assumed level due to such factors as geographical proximity and special trade arrangements between trading economies. The unexplained residual, referred to as the location effect, can be formulated as follows

$\gamma_{i j}=\frac{x_{i j}^{t}}{\bar{x}_{i j}^{t}}=\frac{x_{i j}^{t}}{\alpha_{i} \beta_{j} x_{i j}^{0}}$

Rearranging the above formula, Equation 14A.5 can be expressed as

$$
x_{i j}^{t}=\alpha_{i} \beta_{j} \gamma_{i j} x_{i j}^{0}
$$


Thus, changes in economy is exports between time $t$ and 0 can be decomposed into the following three components

$$
\begin{aligned}
& \Delta X_{i}=X_{i}^{t}-X_{i}^{0}=\sum_{j} x_{i j}^{t}-\sum_{j} x_{i j}^{0}=\sum_{j} \alpha_{i} \beta_{j} \gamma_{i j} x_{i j}^{o}-\sum_{j} x_{i j}^{0} \\
& =\sum_{j}\left(\beta_{j}-1\right) x_{i j}^{0}+\sum_{j}\left(\alpha_{i}-1\right) \beta_{j} x_{i j}^{0}+\sum_{j} \alpha_{i} \beta_{j}\left(\gamma_{i j}-1\right) x_{i j}^{0}
\end{aligned}
$$

The first component of the right-hand side of Equation 14A.7 is the demand effect, the second one is the competitiveness effect, and the third one is the location effect.

\section{Appendix 14B: The calculation formula on impacts of final demand on regional value added}

The intermediate transaction segments, given in the Asian International Input-Output Table 1995, include ten economies, namely Indonesia, Malaysia, the Philippines, Singapore, Thailand, China, Taiwan, Korea, Japan and the United States. Let $B=\left(b_{i j}^{\alpha \beta}\right)$ denote the 'Inverse Matrix', known as the 'Leontief Inverse', where

$\alpha$ denotes a supplying economy ( $\alpha$ represents the 10 economies)

$\beta$ denotes a demanding economy ( $\beta$ represents the 10 economies)

$i$ denotes the $i$-th industry of economy $\alpha(1 \leq i \leq n)$

$j$ denotes the $j$-th industry of economy $\beta \quad(1 \leq j \leq n)$

$n$ is the number of industries

Thus $B$ is the matrix with the size of $10 \mathrm{n} \times 10 \mathrm{n}$. Herein, the $10 \mathrm{n}$ dimensional vector $V$ is defined as follows

$V=\left[\mathrm{V}_{1}^{\prime}, \ldots, \mathrm{V}_{\mathrm{n}}^{\prime}, \ldots, \mathrm{W}_{1}, \ldots, \mathrm{V}_{\mathrm{n}}^{\mathrm{U}}\right]$

where $V^{E}{ }_{j}$ is defined as the ratio of value added to gross inputs in industry $j$ of economy $E$.

The ratio of international division of labour by economy $E$, when one unit of demand for industry $j$ of China is created, can be defined as follows

$$
I D L_{j}^{E}=\frac{\sum_{i} V_{i}^{E} b_{i j}^{E C}}{\sum_{E} \sum_{i} V_{i}^{E} b_{i j}^{E C}}
$$

where $\sum_{E}, \sum_{i}$ are summations over 10 economies and all the industries respectively (Table 14B.1). 


\section{Appendix table B14.1 Listed industries by sectors}

$\begin{array}{ll}\text { Number } & \text { Sector } \\ 1 & \text { Agriculture, livestock, forestry and fishery } \\ 2 & \text { Crude petroleum and natural gas } \\ 3 & \text { Other mining } \\ 4 & \text { Food, beverage and tobacco } \\ 5 & \text { Textile, leather, and the products thereof } \\ 6 & \text { Timber and wooden products } \\ 7 & \text { Pulp, paper and printing } \\ 8 & \text { Chemical products } \\ 9 & \text { Petroleum and petro products } \\ 10 & \text { Rubber products } \\ 11 & \text { Non-metallic mineral products } \\ 12 & \text { Metal products } \\ 13 & \text { Machinery } \\ 14 & \text { Transport equipment } \\ 15 & \text { Other manufacturing products }\end{array}$

Source: Authors' calculations. 


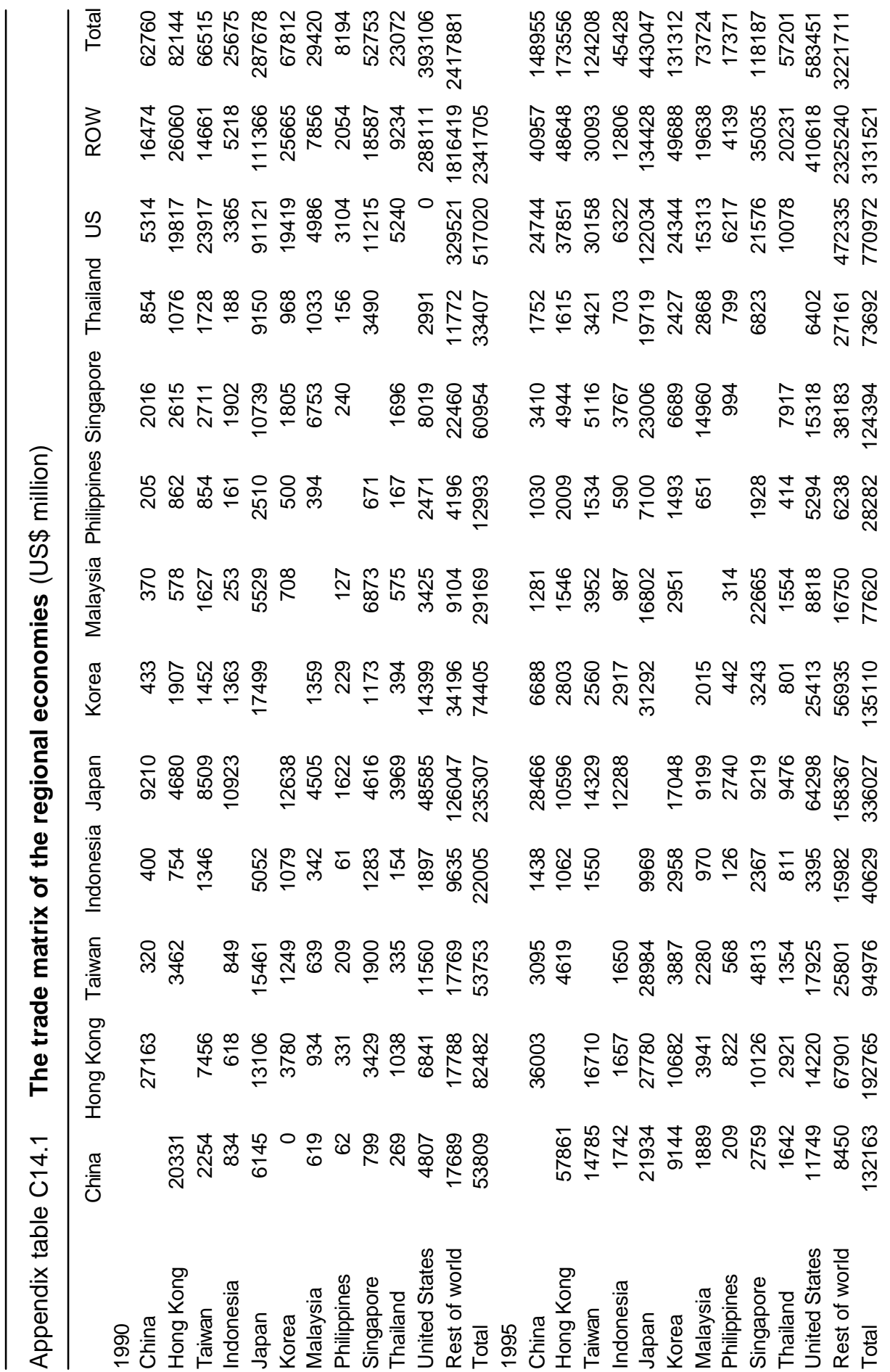




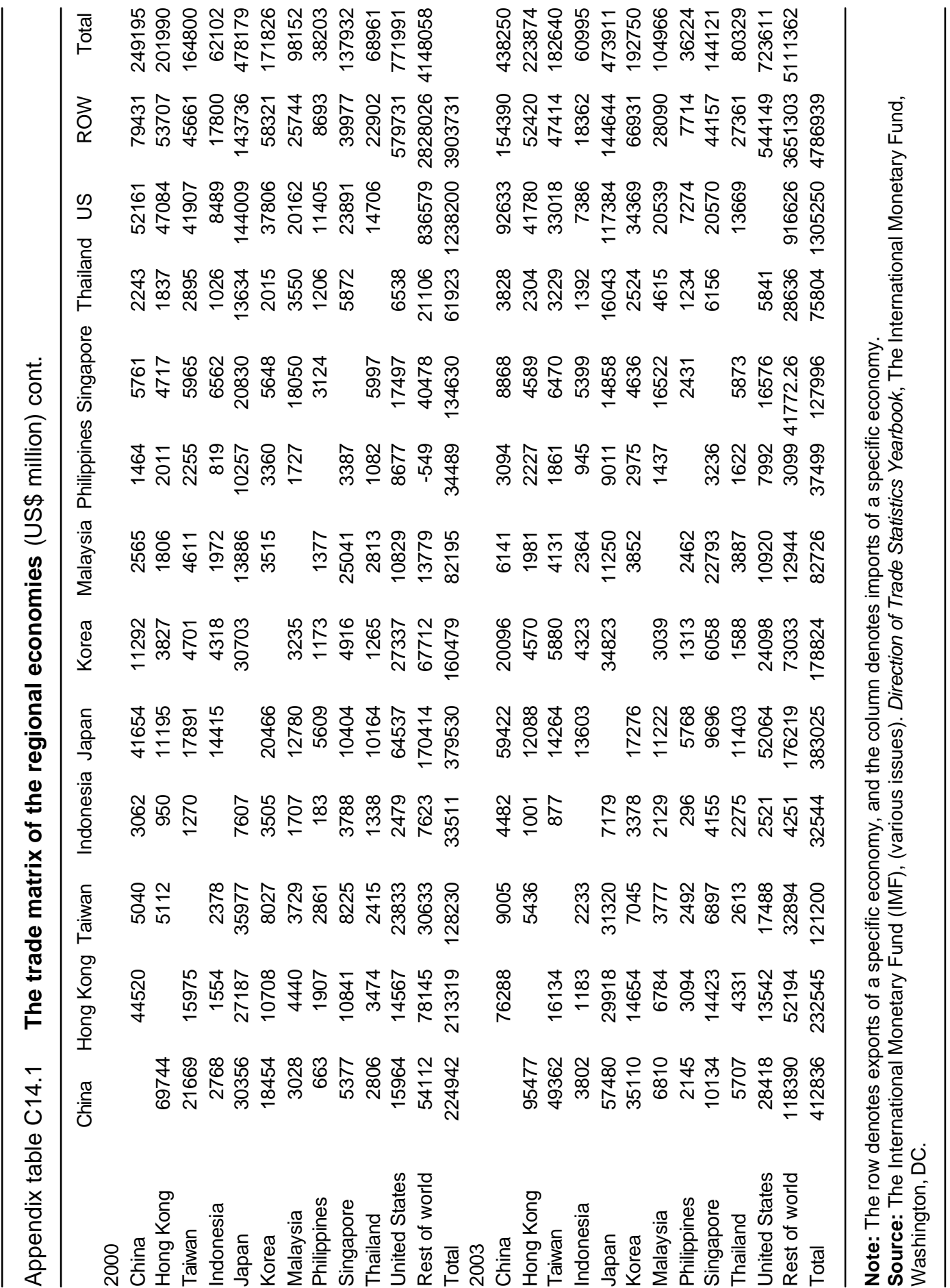

